University of Nebraska - Lincoln

DigitalCommons@University of Nebraska - Lincoln

\title{
Vulnerability of grazing and confined livestock in the Northern Great Plains to projected mid and late-twenty-first century climate
}

Justin D. Derner

David Briske

Matt Reeves

T. M. Brown-Brandl

Miranda Meehan

See next page for additional authors

Follow this and additional works at: https://digitalcommons.unl.edu/usdaarsfacpub

This Article is brought to you for free and open access by the U.S. Department of Agriculture: Agricultural Research Service, Lincoln, Nebraska at DigitalCommons@University of Nebraska - Lincoln. It has been accepted for inclusion in Publications from USDA-ARS / UNL Faculty by an authorized administrator of DigitalCommons@University of Nebraska - Lincoln. 


\section{Authors}

Justin D. Derner, David Briske, Matt Reeves, T. M. Brown-Brandl, Miranda Meehan, Dana M. Blumenthal, William E. Riebsame, David Augustine, Hailey Wilmer, Derek Scasta, John Hendrickson, Jerry Volesky, Laura Edwards, and Dannele Peck 


\title{
Vulnerability of grazing and confined livestock in the Northern Great Plains to projected mid- and late-twenty-first century climate
}

\author{
Justin Derner ${ }^{1}$ (D) David Briske ${ }^{2} \cdot$ Matt Reeves $^{3}$ • \\ Tami Brown-Brandl ${ }^{4}$ - Miranda Meehan ${ }^{5}$. \\ Dana Blumenthal ${ }^{6} \cdot$ William Travis ${ }^{7}$. \\ David Augustine $^{6} \cdot$ Hailey Wilmer ${ }^{6} \cdot$ Derek Scasta $^{8}$. \\ John Hendrickson ${ }^{9} \cdot$ Jerry Volesky $^{10}$. \\ Laura Edwards ${ }^{11}$ • Dannele Peck ${ }^{6}$
}

Received: 28 November 2016 / Accepted: 7 July 2017 / Published online: 24 July 2017

(C) Springer Science+Business Media Dordrecht (outside the USA) 2017

\begin{abstract}
The Northern Great Plains (NGP) region of the USA - which comprises Montana, Wyoming, Colorado, North Dakota, South Dakota, and Nebraska - is a largely rural area that provides numerous ecosystem services, including livestock products, cultural services, and conservation of biological diversity. The region contains $25 \%$ of the Nation's beef cattle and approximately one-third of the confined beef cattle, as well as the largest remaining native prairie in the US - the Northern Mixedgrass Prairie. With rising atmospheric $\mathrm{CO}_{2}$, the NGP is projected to experience warmer and longer growing seasons, greater climatic variability, and
\end{abstract}

This article is part of a Special Issue on "Vulnerability Assessment of US Agriculture and Forests developed by the USDA Climate Hubs" edited by Jerry L. Hatfield, Rachel Steele, Beatrice van Horne, and William Gould.

Justin Derner

Justin.Derner@ars.usda.gov

David Briske

dbriske@tamu.edu

Matt Reeves

mreeves@fs.fed.us

Tami Brown-Brandl

tami.brownbrandl@ars.usda.gov

Miranda Meehan

Miranda.meehan@ndsu.edu

Dana Blumenthal

dana.blumenthal@ars.usda.gov

William Travis

William.travis@colorado.edu 
more extreme events (e.g., increased occurrence of large precipitation events). These climatic changes may affect livestock production both directly via physiological impacts on animals and indirectly via modifications to forage, invasion of undesirable plants, and increased exposure to parasites. This raises concerns about the vulnerability of grazing livestock operations and confined livestock operations to projected changes in mid- (2050) and late(2085) twenty-first century climate. Our objectives are to (1) describe the NGP's exposure to temperature and precipitation trends, inter-annual variability, and extreme events; (2) evaluate the sensitivity of beef cattle production to direct and indirect effects imposed by these projected climatic changes; and (3) provide a typology of adaptation strategies to minimize adverse consequences of projected changes and maximize beneficial consequences. Agricultural managers have developed considerable adaptive capacity to contend with environmental and economic variability. However, projected climatic changes, especially the increased frequency and magnitude of weather extremes, will require even greater adaptive capacity to maintain viable production systems. Consequently, regional vulnerability to projected climatic changes will be determined not only by ecological responses but also by the adaptive capacity of

\author{
David Augustine \\ david.augustine@ars.usda.gov \\ Hailey Wilmer \\ hailey.wilmer@ars.usda.gov \\ Derek Scasta \\ jscasta@uwyo.edu \\ John Hendrickson \\ john.hendrickson@ars.usda.gov \\ Jerry Volesky \\ jerry.volesky@unl.edu \\ Laura Edwards \\ laura.edwards@sdstate.edu \\ Dannele Peck \\ dannele.peck@ars.usda.gov
}

USDA-ARS, 8408 Hildreth Road, Cheyenne, WY 82009, USA

2 Texas A\&M University, Centeq Bldg, Rm 130C, MS2120 TAMU, College Station, TX 77843, USA

3 USDA-FS, 800 E. Beckwith, Missoula, MT 59801, USA

4 USDA-ARS, State Spur 18D, Clay Center, NE 68933, USA

5 North Dakota State University, 1300 Albrecht Blvd, Hultz Hall, Fargo, ND, USA

6 USDA-ARS, 1701 Centre Ave, Fort Collins, CO 80526, USA

7 Western Water Association, University of Colorado Boulder, 216 UCB, Boulder, CO 80309, USA

8 University of Wyoming, Agriculture Bldg 2004, 1000 E. University Ave, Laramie, WY 82071, USA

9 USDA-ARS, P.O. Box 459, Mandan, ND 58554, USA

10 University of Nebraska-Lincoln, WCREC, 402 W. State Farm Road, North Platte, NE 69101, USA

11 South Dakota State University, Brookings, SD 57007, USA 
individual managers. Adaptive capacity in the NGP will differ from other regions, in part because projections suggest some opportunities for increased livestock production. Adaptations in both grazing and confined beef cattle systems will require enhanced decision-making skills capable of integrating biophysical, social, and economic considerations. Social learning networks that support integration of experimental and experiential knowledge - such as lessons learned from early adopters and involvement with science-based organizations - can help enhance decision-making and climate adaptation planning. Many adaptations have already been implemented by a subset of producers in this region, providing opportunities for assessment, further development, and greater adoption. Context-specific decision-making can also be enhanced through science-management partnerships, which aim to build adaptive capacity that recognizes multiple production and conservation/environmental goals.

\section{Introduction}

The Northern Great Plains (NGP) of the USA is an important agricultural and ecological region encompassing Montana, Wyoming, Colorado, North Dakota, South Dakota, and Nebraska. This region has 25\% of the nation's beef cows, sheep, and lambs (NASS 2012), $34 \%$ of the nation's cattle on feed (NASS 2012), and significant numbers of dairy cattle and hogs. It is therefore of critical importance to national and international food security. Agricultural producers manage more than one-third of the USA's 140 million ha of pasture and rangeland, including the largest remaining tract of native rangeland in North America - the Northern Mixedgrass Prairie. This region is projected to have rising atmospheric $\mathrm{CO}_{2}$, warming surface temperatures, longer growing seasons (Badeck et al. 2004), increased weather variability, and more extreme events (e.g., deluges, longer and more severe droughts) (Nardone et al. 2010). This raises the question "How vulnerable are livestock producers to climatic changes and extreme weather events that exceed those experienced in the past?"

Vulnerability describes the degree to which a system is likely to experience harm due to exposure to a hazard (i.e., a disturbance or stressor). Vulnerability consists of three interrelated components - exposure, sensitivity, and adaptive capacity (Adger 2006). In the context of climatic changes, exposure refers to the direct effects of warming, modified precipitation regimes, a greater frequency and intensity of extreme weather events, and increased weather variability (Troy et al. 2015) on the agricultural sector and ecological processes (Hamilton et al. 2016). Exposure also involves indirect effects of climatic change, such as expansion of invasive plants, increasing wildfires, and increased incidence of pathogens and parasites; for the NGP region, this also includes the threat involving land-use change from pasture and rangeland to cropland and cropping system changes (e.g., Wright and Wimberly 2013; Lark et al. 2015; Rashford et al. 2016). Sensitivity describes the magnitude of impact on systems, both ecological and economic, following exposure to hazards or stressors. The NGP region is unique relative to much of the USA in that it is experiencing both beneficial and detrimental consequences of climate change (Briske et al. 2015). For example, warmer winters will reduce the duration of supplemental livestock feeding provided that there is forage carryover from the current growing season available to graze during the dormant season. Rising atmospheric $\mathrm{CO}_{2}$, plus warming, will increase pasture and rangeland productivity (Mueller et al. 2016) though forage quality (e.g., nitrogen, N, content may decline (Milchunas et al. 2005) and invasive plants increase in abundance and competitive ability (Blumenthal et al. 2013, 2016). Collectively, these changes are likely to increase the capacity for livestock production. Lastly, 
adaptive capacity - the ability of humans to anticipate and respond to potential or actual exposure to various stressors (Adger 2006) - is an essential component of agriculture vulnerability because it establishes the foundation upon which adaptation strategies are conceptualized, implemented, and evaluated (Vincent 2007, Nelson et al. 2010). Yet change of any kind is difficult, so the development, adoption, and implementation of climate change adaptations pose challenges for both grazing and confined livestock operations (Joyce et al. 2013; Briske et al. 2015).

The goal of this paper is to assess the vulnerability of livestock grazing systems and confined livestock operations in the NGP to projected climate conditions for the mid(2050) and late- (2085) twenty-first century. Precipitation and temperature, including their intra- and inter-annual variability, are the primary climate variables that influence grazing lands and livestock (Polley et al. 2013). Our specific objectives are to (1) describe the NGP's exposure to projected temperatures and precipitation, (2) evaluate the sensitivity of beef cattle production to direct and indirect consequences of the projected climatic conditions, and (3) provide a typology of adaptation strategies to optimize the benefits and minimize the adverse consequences of climatic changes.

\section{Exposure-predicted climatic conditions for mid- (2050) and late- (2085) twenty-first century}

\subsection{Temperature}

Across the NGP, daily average temperatures are projected to increase $2.2-3.3{ }^{\circ} \mathrm{C}$ by 2050 , with an increase of $4.4-6.7^{\circ} \mathrm{C}$ by 2085 . Annual 5-day maximum temperatures are predicted to increase $3.3-4.4{ }^{\circ} \mathrm{C}$ by 2050 , relative to the reference period of 1976-2005 ("Downscaled CMIP5 Climate and Hydrology Projections" archive at http://gdo-dcp.ucllnl.org/downscaled cmip_projections/, Pierce et al. 2014, 2015). Maximum temperatures are expected to continue rising through 2085 , with $5.6^{\circ} \mathrm{C}$ increases south of the South Dakota-Nebraska border and 6.7 ${ }^{\circ} \mathrm{C}$ increases further north. Number of days with maximum temperature exceeding $35{ }^{\circ} \mathrm{C}$ is projected to increase by 20-40 days across the region by 2050. By 2085, a further increase of 20 additional days with maximum temperatures exceeding $35^{\circ} \mathrm{C}$ is projected.

Concomitantly, annual 5-day minimum temperatures are projected to increase $2.2^{\circ} \mathrm{C}$ in the southwestern part of the NGP, and $5.6{ }^{\circ} \mathrm{C}$ in the northeastern part of the NGP by 2050 . This geographical trend continues through 2085 with the magnitude of warming doubling to $4.4^{\circ} \mathrm{C}$ in the southwest and an $8.9{ }^{\circ} \mathrm{C}$ increase in the northeast. The number of days where the minimum temperature is less than $0{ }^{\circ} \mathrm{C}$ (freezing) decreases by $20-40$ days in 2050 , and by 50-70 days in 2085. Higher minimum temperatures are expected to both harm and help livestock production. They will, for example, increase the abundance of some parasites and pathogens (as discussed later). However, they will also markedly reduce livestock producers' winter feed costs - often the largest production expense (McCartney et al. 2004). The net effect of warming on livestock production is a complex function of many direct and indirect impacts, whose relative magnitudes will vary throughout the NGP.

\subsection{Precipitation}

A majority of the NGP is projected to experience a $100 \%$ increase in 5.1-cm rainfall events by 2050, with this trend continuing through 2085 ("Downscaled CMIP5 Climate and Hydrology 
Projections" archive at http://gdo-dcp.ucllnl.org/downscaled_cmip_projections/, Pierce et al. 2014,2015 ). The probability of rainfall events exceeding $7.6 \mathrm{~cm}$ increases $100 \%$ in the eastern $1 / 3$ of the region - areas predominantly east of the 100th meridian - for both 2050 and 2085. Maximum 1-day precipitation is projected to increase $10-30 \%$ by 2050 , and $15-40 \%$ by 2085. The annual longest consecutive dry-day period in the NGP is projected to remain similar to the reference period (1976-2005), or even 3 days shorter, in both mid- and late-twenty-first century. This projection is unique among the geographical regions of the USA.

\section{Sensitivity of livestock production}

\subsection{Forage quantity and quality}

The primary outcomes of climate change - rising atmospheric $\mathrm{CO}_{2}$ concentration, atmospheric warming, and modified amounts and temporal patterns of precipitation-affect soil-water availability and therefore many aspects of livestock production and rangeland function (Izaurralde et al. 2011; Polley et al. 2013). Livestock production will be affected both directly, via physiological impacts on animal performance, and indirectly via modifications to forage composition, quantity and quality, and ectoparasite dynamics (Polley et al. 2013).

Forage production, according to modeled responses of NGP vegetation, is likely to increase about $5-10 \%$ by 2050 in response to increasing minimum annual temperatures and $\mathrm{CO}_{2}$ enrichment (Reeves et al. 2014). Total plant production in the Northern Mixedgrass Prairie is consistently increased by experimental atmospheric $\mathrm{CO}_{2}$ enrichment and warming. This is especially true in dry years, due to $\mathrm{CO}_{2}$-induced increases in plant water-use efficiency (Mueller et al. 2016).

Forage availability is a function of multiple interacting variables that may vary in importance throughout the growing season. Warmer temperatures will hasten spring green-up, as well as peak forage availability in the summer, but also allow growth later into the fall (ReyesFox et al. 2014). An earlier peak in forage availability will be due, in part, to decreased abundance of $\mathrm{C}_{4}$ grasses (by more than 50\%) (Mueller et al. 2016). An equivalent increase is projected, though, for more productive $\mathrm{C}_{3}$ grasses (Mueller et al. 2016). Late-season growth can be extended through more efficient plant water-use under dry conditions and elevated $\mathrm{CO}_{2}$ (Reyes-Fox et al. 2014). Earlier vegetation green-up may provide opportunities for grazing livestock operations to calve earlier in the calendar year to better match cow nutrient demand with nutritive quality of forage (Stockton et al. 2007).

Forage quality, like forage availability, is a complex function of multiple factors. For example, although larger individual precipitation events could increase plant productivity by increasing soil-water storage (Heisler-White et al. 2009), forage quality such as plant $\mathrm{N}$ content may decline (Milchunas et al. 2005). A recent meta-analysis of $\mathrm{CO}_{2}$ effects on forage quality reveals that elevated atmospheric $\mathrm{CO}_{2}$ increases total non-structural carbohydrates by an average of $25 \%$, but decreases forage $\mathrm{N}$ content by $8 \%$ (Dumont et al. 2015). However, regional effects of elevated $\mathrm{CO}_{2}$ can vary, with relatively large declines in both forage $\mathrm{N}$ and in vitro digestibility demonstrated in the NGP's semiarid rangelands (Milchunas et al. 2005; Mueller et al. 2016). Unlike elevated $\mathrm{CO}_{2}$, warming has no consistent effects on carbohydrates or $\mathrm{N}$ content of plants (Dumont et al. 2015). In light of $\mathrm{CO}_{2}$ and warming effects, forage $\mathrm{N}$ will likely remain sufficient to meet maintenance requirements of mature livestock (approximately $1 \% \mathrm{~N}$ ), but values less than $1.5 \%$ will be more common under future climates (Milchunas et al. 
2005, Mueller et al. 2016), which could suppress ruminant growth rates and reproduction. Adverse effects of low nutritive value of forage can be offset by monitoring temporal fluctuations in diet quality, providing animals with $\mathrm{N}$ supplements, shifting some storedforage use to late fall, and inter-seeding pastures with legumes (Mortenson et al. 2005; Tolleson and Schafer 2014).

Invasive plants may also become more problematic due to changes in the amount and timing of plant resource availability. For example, elevated $\mathrm{CO}_{2}$ facilitates Linaria dalmatica (Dalmatian toadflax) invasion by increasing the availability of water and carbon (Blumenthal et al. 2013). Warming more than triples seed production of Bromus tectorum (cheatgrass) by increasing its growth during the fall and spring (Blumenthal et al. 2016). Biogeographic models for the NGP suggest that several problematic invaders (including B. tectorum) will become more abundant, but some others (e.g., Euphorbia esula (leafy spurge)) will become less abundant (Bradley et al. 2009). Management of invasive species that thrive under projected climatic conditions will be challenging, but advances in our understanding of the mechanisms that facilitate invasion can help guide adaptation, including more effective use of targeted grazing (Frost et al. 2012), monitoring and suppression in areas of likely expansion, and adaptive timing of grazing to encourage competitive forage species (Rinella and Bellows 2015). For example, producers could turn out their livestock earlier to reduce the competitive ability of invasive plants that grow most vigorously in early spring (Rinella and Bellows 2015).

\subsection{Animal heat stress}

Air temperature is the most important climatic variable contributing to an animal's thermal environment, but humidity, wind speed, solar radiation, and nighttime temperature minimums all have significant effects on livestock heat stress in all types of animal facilities (Mader et al. 2006). Economic losses from heat stress originate from three primary responses: (1) decreased performance (e.g., less feed intake, lowered feed efficiency), (2) decreased reproduction, and (3) increased mortality (St-Pierre et al. 2003). These losses are greatest when animals are confined outdoors in a limited space. For example, feedlot cattle will be responsible for 15$20 \%$ of the estimated annual economic losses for all livestock species due to heat stress (StPierre et al. 2003). Effects of heat stress can be reduced by providing animals with naturally ventilated buildings or shade structures, to protect them from solar radiation, or with mechanically ventilated buildings to protect them from both solar radiation and unreliable wind speeds (Brown-Brandl et al. 2013).

\subsection{Parasites and pathogens}

Earlier spring warming and greater maximum temperatures will potentially escalate ectoparasite exposure (Scasta et al. 2017). For example, face fly (Musca autumnalis) and horn fly (Haematobia irritans) emergence can be predicted using accumulated degree-day thresholds of 70 days at $12{ }^{\circ} \mathrm{C}$ or above (Krafsur and Moon 1997) and 10.5 days of $25{ }^{\circ} \mathrm{C}$ or above (Lysyk 1999), respectively. Projected precipitation changes, coupled with temperature changes, will lead to greater parasite egg and pupae survival, shorter dormancy periods, greater physical activity of parasites, and longer periods of animal exposure (Goulson et al. 2005). Species such as horn flies and biting midges (Culicoides spp., a vector of bluetongue virus), which have historically been restricted to lower elevations, may be able to expand their elevational range upward, resulting in more livestock in the NGP being exposed (Scasta 
2015). Similarly, warmer winters coupled with longer and wetter growing seasons may lead to greater infestation and expansion of ticks, especially into northern latitudes and higher altitudes (Dantas-Torres 2015).

Effects of projected climate change on endoparasites of livestock (e.g., roundworms) are less clear due to seasonal and species variability. For example, an increase in Haemonchus contortus and Teladorsagia circumcincta infection pressure is expected in small ruminants due to accelerated parasite development in winter months. In contrast, a decrease in infection pressure of Ostertagia ostertagi in cattle is expected due to greater parasite mortality from higher temperatures (Rose et al. 2015). Effects of climate change on viral diseases (e.g., bovine viral diarrhea), protozoan pathogens (Neospora caninum), and bacterial infections (e.g., Brucella spp., Bacillus anthracis, Escherichia coli) are even less understood (Hoberg et al. 2008). One hypothesized impact is that changing temperatures and precipitation will affect pathogen persistence in the environment, and hence livestock exposure. Similarly, changes in the spatio-temporal distribution of domestic versus wild ungulates may affect the emergence and transmission of pathogens within and between species (Hoberg et al. 2008).

\subsection{Riparian structure and function}

Peak streamflow from snowmelt in the NGP has traditionally occurred during April-July, but is now occurring 1-2 weeks earlier due to increased temperatures (Ryberg et al. 2016). With future warming, timing of snowmelt and peak flows will continue to advance. Extreme rainfall events, which are predicted to double in the next 35 years, will increase stream velocity. In turn, stress on stream beds and banks will escalate, resulting in increased erosion potential via scouring and downcutting. These impacts are expected to be worse on streams with confined floodplains, steep gradients, or fine channel material (alluvial and lacustrine) (Bear et al. 2012).

Stream banks can be stabilized with desirable riparian vegetation, which dissipates energy of flood waters, increases trapping of sediments in its extensive root system, and ultimately decreases erosion (Gregory et al. 1991; Shafroth et al. 2002). Maintaining native, riparian vegetation through management of grazing (timing, intensity, and duration) can also increase infiltration and minimize changes to flood regimes and stream temperatures (Chambers et al. 2012). In contrast, invasive species such as shallow-rooted Kentucky bluegrass (Poa pratensis) and smooth bromegrass (B. inermis) — which are more competitive under projected climatic conditions - could negatively affect bank stability and channel morphology (Gregory et al. 1991). Targeted grazing can reduce non-native species within riparian vegetation while increasing deep-rooted grass and sedge species (Evans et al. 2004). Development of offstream water and shade can prevent livestock from concentrating in riparian areas, thereby decreasing the potential for bank erosion (Grudzinski et al. 2016). The use of genetic selection or development of new cattle breeds that are genetically predisposed to graze uplands or slopes of rugged terrain is another adaptation strategy to reduce impacts on riparian vegetation (Bailey et al. 2015).

\section{Adaptive capacity and climate risk management in livestock systems}

Livestock managers have developed considerable adaptive capacity to contend with both environmental and economic variability. However, projected increases in the frequency and magnitude of climatic extremes will require even greater adaptive capacity to maintain viable 
livestock production systems (Howden et al. 2007; Joyce et al. 2013). Adaptations can include incremental adjustments, which maintain viability of current production enterprises through added performance margins, technical improvements, shortened planning horizons, and noregret adaptations that make sense in a range of future conditions (Hallegatte 2009). Alternatively, adaptations can transform the system in more fundamental ways, for example, by altering an operation's scale, goals, or location (Kates et al. 2012; Rickards and Howden 2012). Adaptation is an iterative risk-management strategy that involves learning and adjusting, rather than adhering to a prescribed set of technologies or policies (Nelson et al. 2007; Joyce et al. 2013). It requires careful assessment of the feasibility of current management under climatic changes, and frequent evaluation of the effectiveness of adaptations under changing climate.

A region's vulnerability to climatic change will be determined not only by ecological responses but also by the adaptive capacity of individual managers. Strategic-thinking skills and social capital may be more important to the success of adaptation planning than technical capability or considerations (Marshall 2010). Managers with limited social, economic, or environmental flexibility are especially vulnerable to weather variation (Marshall 2010), and likely to climatic change as well. Vulnerability has also been correlated with strong place and livelihood attachment, and a reluctance to diversify livestock operations, particularly among aging, independent managers (Marshall 2010; Marshall and Smajg1 2013). Income and size of a livestock production enterprise positively influence the adoption of innovative practices. For example, managers with larger properties tend to implement a greater number of management practices to increase enterprise flexibility and lessen the impacts of drought (Kachergis et al. 2014). Adaptive capacity clearly varies among managers; they have diverse levels of emotional and financial flexibility, interest in adapting to climatic change, capacity to manage risk, and ability to plan, learn, and reorganize (Marshall and Smajgl 2013). For these reasons, contextspecific interventions and science-management partnerships are needed to enhance adaptive capacity among diverse managers, rather than assuming that a single homogenous approach will effectively accommodate all managers (Marshall and Smajgl 2013; Joyce et al. 2013).

\subsection{Adaptation strategies for livestock production systems}

Adaptation in grazing and confined livestock systems will require enhanced decision-making that integrates biophysical, social, and economic considerations (Nardone et al. 2010). Table 1 summarizes an assortment of adaptation strategies, which vary greatly in the extent of modification required, timing of implementation, specificity of impact, potential for success or failure, and likelihood of adoption given managers' diverse adaptive capacity (Briske et al. 2015). Many of the potential adaptations identified in Table 1 are already practiced (to varying degrees) in the NGP, providing natural opportunities for peer-to-peer learning and incremental improvements of existing adaptation strategies. Adaptations that could be further explored include using livestock as ecosystem engineers (Derner et al. 2009), shifting the composition of livestock breeds or species (Peinetti et al. 2011), developing robust drought contingency plans (Kachergis et al. 2014), and building flexibility into herd management plans (Torell et al. 2010; Derner and Augustine 2016).

Adaptive capacity within the agricultural community can be strengthened though the development of social learning networks that included learning from peers and collaboration with science-based organizations. It is critical that development of adaptive capacity focus on context-specific decision-making at the enterprise level (Roche et al. 2015). Adaptive grazing 
Table 1 Typology of incremental adaptation, and systems adaptation and transformational adaptation strategies (Rickards and Howden 2012) for grazing and confined livestock operations in the Northern Great Plains

Incremental adaptation strategies

Systems adaptation and transformational adaptation strategies

Grazing livestock

Adaptive grazing management

Altered timing of grazing and longer grazing

seasons

Proactive flexible stocking

Nitrogen supplements to offset low forage

quality

Inter-seeding with nitrogen-fixing legumes

Targeted grazing of invasive plants and riparian vegetation

Monitoring management outcomes to support subsequent decision-making

Monitoring and suppression of invasive plants

in areas of likely invasion

Cattle breeds genetically predisposed to graze on uplands or slopes of rugged terrain

Modification of livestock enterprise structure

Confined Livestock

Altered pen direction, orientation, and slope

Increased insulation in facilities

Tunnel ventilation

Stir fans

Shade

Sprinkler cooling

High-pressure misting

Evaporative cooling pads
Livestock as ecosystem engineers

Robust contingency drought/deluge planning

Collaborative adaptive management

Shift in livestock breeds/species

Geographic relocation of production enterprises

Shift to new production enterprises emphasizing alternative ecosystem services

Breeds locally adapted to hot and fluctuating weather regimes

Strategic, cost-effective nitrogen supplementation informed by diet quality monitoring, and associated decision-support tools

Social learning networks

Altered designs of containment facilities for manure and runoff resulting from increased frequency of extreme precipitation events

Genetic changes for greater heat stress tolerance (species, color, hair coat thickness, etc.)

Geographical shift in primary areas of confined livestock facilities

management is capable of exploring important complexities in a system, such as how to match animal demand with forage production variability across years and within the grazing season. In drought-prone rangelands, adaptive grazing management relies heavily on enterprise and management flexibility, specifically (1) matching forage availability with demand through flexibility in the proportion of cow-calf pairs versus yearlings and (2) using relevant monitoring metrics to inform flexible decisions that can reduce risk (Derner and Augustine 2016). Flexibility of enterprises and management also positions producers to make better use of weather and climate forecasts which can further reduce vulnerability to drought.

In regions of highly variable forage production, maintaining grazing flexibility by shifting from cow-calf enterprises to mixed cow-calf and yearling cattle (stocker) enterprise may be critical for economic success. This shift in strategy would allow producers to sustain desired cow herd genetics by maintaining a stable, albeit smaller, number of breeding cows more consistently by eliminating the need to liquidate cows during drought and restock following 
the end of drought. However, this form of flexibility imposes additional costs and financial risks that may be unattractive to some managers (Torell et al. 2010). Limited adoption of flexible stocking strategies may also be due to uncertainty of seasonal precipitation forecasts (Derner et al. 2012), and inherent constraints in enterprise structure, such as maintaining desired herd genetics. Regarding enterprise structure, increased climatic variability may require greater use of stored forage (e.g., grass banks, hay supplies), increased contingency planning, and the ability to alter herd sizes and production systems, all of which require capital investment (Didier and Brunson 2004). Policies designed in a way that avoid perverse incentives, which could unintentionally increase vulnerability (Lark et al. 2015), could provide financial incentives to increase adoption of various risk-management strategies, including contingency planning and risk-management tools like insurance, if designed to avoid moral hazard (Muller et al. 2011). Decision tools could help producers explore trade-offs between profitability and financial risk of various adaptation strategies, perhaps increasing their willingness to experiment with them (e.g., Ritten et al. 2010; Moss et al. 2014).

In cases where incremental adaptation proves insufficient to sustain agricultural livelihoods, systems adaptation and transformational adaptation may be necessary (Rickards and Howden 2012). Systems adaptation and transformational adaptation involve making major changes in the production system that emphasizes the provision of alternative ecosystem services that are more consistent with the emerging climatic conditions (Kates et al. 2012; Joyce et al. 2013). For example, transformational adaptation in the NGP, in response to warmer and wetter conditions, may involve conversion of from extensive to more intensive agricultural systems that may result in substantial trade-offs among ecosystem services in the region. Consequently, adaptation strategies should be designed to accommodate both agricultural production and conservation goals such as geographical relocation of a producer's enterprise to climatic conditions more conducive to their success (Kates et al. 2012; Joyce et al. 2013).

\subsection{Adaptation strategies for confined livestock}

Projected warming will increase the potential for heat stress for both grazing and confined livestock, but the concern is greater for confined animals. For outdoor-confined operations, temperatures can exceed $55^{\circ} \mathrm{C}$ in an unshaded feedlot on hot, sunny days (Brown-Brandl et al. 2010). An outdoor-confined animal's microclimate is defined by pen location, slope, and surface maintenance. Slope affects the angle of incident solar radiation and the heat load that animals receive. In the northern hemisphere, south, southwest, and west-facing pens receive the most intense solar radiation (Busby and Loy 1996). Regarding surface maintenance, manure has greater water-holding capacity than soil (Khaleel et al. 1981), so a wet manuresoil mixture will prevent water from draining out of pens after rainfall events. This standing water then increases humidity in the animal's local environment, making hot days feel hotter and cool days feel cooler. Containment facilities for managing animal waste and runoff will need to be adapted to account for projected increases in the frequency of extreme rainfall events.

Adaptation strategies to reduce heat stress and increase well-being for outdoor-confined animals include shade structures, sprinkler cooling, high-pressure misting, or evaporative cooling pads. Similarly, heat stress of indoor-confined animals can be reduced by increasing their housing facility's insulation, and installing stir fans, tunnel ventilation, or an evaporative cooling system. Stir fans and tunnel ventilation increase air velocity over animals to increase 
convective heat loss, whereas evaporative cooling directly cools the air around the animals. It is known that windbreaks can be detrimental on hot days by reducing convective animal cooling (Mader et al. 1997), though they are beneficial to animals on cold days by reducing wind-chill effects (Mader 2003). Spanning all three types of livestock production systems (rangeland, outdoor-confined, indoor-confined), one final adaptation strategy for a warming climate is selecting heat-tolerant breeds or specialized genotypes such as Brahman, Criollo, Santa Gertrudis, Senepol, Tuli, and associated crosses (Gaughan et al. 2010; Hammond et al. 1998; Peinetti et al. 2011). Little is known, however, about genetically based tolerance to extreme temperature fluctuations, and concerns exist regarding the marketability of these alternative breeds or specialized genotypes.

\section{Conclusion}

Projections of increasing atmospheric $\mathrm{CO}_{2}$ concentrations, warmer temperatures, and more intense rainfall events for mid- and late-twenty-first century offer unique challenges and opportunities for livestock production in the NGP. Livestock managers in the NGP may benefit from increases in forage production and shorter, milder winters - provided they can appropriately supplement livestock to mitigate declining forage quality, and are prepared to absorb and adapt to extreme weather events (e.g., deluges, heat waves, and winter storms). Adaptations in both grazing and confined livestock systems will require enhanced decision-making skills capable of integrating biophysical, social, and economic considerations, as socio-economic reasons are often prominent in producers' decisions regarding adoption of adaptation strategies (Marshall 2010; Nardone et al. 2010). In turn, this will require development of greater adaptive capacity for livestock producers to contend with the opportunities and challenges associated with regional climate change. The establishment of social learning networks, including peer-to-peer learning, where lessons from early adopters can be used to improve existing adaptation strategies and encourage others to experiment with them, will be essential for development of effective adaptation strategies (Didier and Brunson 2004). In fact, many adaptations have already been implemented, to varying degrees, in the NGP, providing opportunities for assessment, further development, and increased adoption. For adaptations that have not yet been implemented, decision tools can empower producers to explore the associated costbenefit ratios, risks, and trade-offs among ecosystem services. Locally relevant climate data and weather forecasts can also be incorporated into these decision tools, to increase producers' adoption of new information to support management decision-making. The effectiveness of adaptation strategies to content with climate change will require contextspecific decision-making skills that recognize both production and conservation goals.

\section{References}

Adger WN (2006) Vulnerability. Glob Environ Chang 15:268-281

Badeck FW, Bondeau A, Bottcher K, Doktor D, Lucht W, Schaber J, Sitch S (2004) Responses of spring phenology to climate change. New Phytol 162:295-309

Bailey DW, Lunt S, Lipka A, Thomas MG, Medrano JF, Cánovas A, Rincon G, Stephenson MB, Jensen D (2015) Genetic influences on cattle grazing distribution: association of genetic markers with terrain use in cattle. Rangel Ecolog Manag 68:142-149 
Bear DA, Russell JR, Tufekcioglu M, Isenhart TM, Morrical DG, Kovar JL (2012) Stocking rate and riparian vegetation effects on physical characteristics of riparian zones of Midwestern pastures. Rangel Ecol Manag 65(2):119-128

Blumenthal DM, Resco V, Morgan JA, Williams DG, LeCain DR, Hardy EM, Pendall E, Bladyka E (2013) Invasive forb benefits from water savings by native plants and carbon fertilization under elevated $\mathrm{CO}_{2}$ and warming. New Phytol. doi:10.1111/nph.12459

Blumenthal DM, Kray JA, Ortmans W, Ziska LH, Pendall E (2016) Cheatgrass is favored by warming but not $\mathrm{CO}_{2}$ enrichment in a semi-arid grassland. Glob Chang Biol 22:3026-3038

Bradley BA, Oppenheimber M, Wilcove DS (2009) Climate change and plant invasions: restoration opportunities ahead? Glob Chang Biol 15:1511-1521

Briske DD, Zhao M, Han G, Xiu C, Kemp DR (2015) Strategies to alleviate poverty and grassland degradation in Inner Mongolia: intensification vs production efficiency of livestock systems. J Environ Manag 152:177182

Brown-Brandl TM, Eigenberg A, Nienaber JA (2010) Water spray cooling during handling of feedlot cattle. Intl J Biometeor 54:609-616

Brown-Brandl TM, Eigenberg RA, Nienaber JA (2013) Benefits of providing shade to feedlot cattle of different breeds. Trans Agric Biol Eng 56:1563-1570

Busby D, Loy D (1996) Heat stress in feedlot cattle: producer survey results. Pages 108-110 in Iowa State University beef research report AS-632. Iowa State University, Ames, IA

Chambers PA, Culp JM, Roberts ES, Bowerman M (2012) Development of environmental thresholds for streams in agricultural watersheds. J Environ Qual 41:1-6

Dantas-Torres F (2015) Climate change, biodiversity, ticks and tick-borne diseases: the butterfly effect. Intl J Parasitolog: Parasit Wildl 4(3):452-461

Derner JD, Augustine DJ (2016) Adaptive management for drought on rangelands. Rangel 38:211-215

Derner JD, Lauenroth WK, Stapp P, Augustine DJ (2009) Livestock as ecosystem engineers for grassland bird habitat in the western Great Plains of North America. Rangel Ecolog Manag 62:111-118

Derner JD, Augustine DJ, Ascough JC II, Ahuja LR (2012) Opportunities for increasing utility of models for rangeland management. Rangel Ecolog Manag 65:623-631

Didier EA, Brunson MW (2004) Adoption of range management innovations by Utah ranchers. Range Ecol Manag 57:330-336

Dumont B, Andueza D, Niderkorn V, Lüscher A, Porqueddu C, Picon-Cochard C (2015) A meta-analysis of climate change effects on forage quality in grasslands: specificities of mountain and Mediterranean areas. Grass Forage Sci 70:239-254

Evans SG, Pelster AJ, Leininger WC, Trlica MJ (2004) Diet selection of cattle grazing a montane riparian community. J Range Manag 57:539-545

Frost R, Walker J, Madsen C, Holes R, Lehfeldt J, Cunningham J, Voth K, Welling B, Davis TZ, Bradford D, Malot J, Sullivan J (2012) Targeted grazing: applying the research to the land. Rangel 34:2-10

Gaughan JB, Mader TL, Holt SM, Sullivan ML, Hahn GL (2010) Assessing the heat tolerance of 17 beef cattle genotypes. Intl J Biometeor 54:617-627

Goulson D, Derwent LC, Hanley ME, Dunn DW, Abolins SR (2005) Predicting calyptrate fly populations from the weather, and probable consequences of climate change. J. Appl Ecol 42:795-804

Gregory SV, Swanson FJ, McKee WA, Cummins KW (1991) An ecosystem perspective of riparian zones. BioSci 41:540-551

Grudzinski BP, Daniels MD, Anibas K, Spencer D (2016) Bison and cattle grazing management, bare ground coverage, and links to suspended sediment concentrations in grassland streams. J Amer Water Res Assoc 52(1):16-30

Hallegatte S (2009) Strategies to adapt to an uncertain climate change. Glob Environ Chang 19(2):240-247. doi:10.1016/j.gloenvcha.2008.12.003

Hamilton TW, Ritten JP, Bastian CT, Derner JD, Tanaka JA (2016) Economic impacts of increasing seasonal precipitation variation on southeast Wyoming cow-calf enterprises. Rangel Ecol Manag 69(6):465-473

Hammond AC, Chase CC, Bowers EJ, Olson TA, Randel RD (1998) Heat tolerance in Tuli-, Senepol-, and Brahman-sired F1 Angus heifers in Florida. J Ani Sci 76:1568-1577

Heisler-White JL, Blair JM, Kelly EF, Harmoney K, Knapp AK (2009) Contingent productivity responses to more extreme rainfall regimes across a grassland biome. Glob Chang Biol 15:2894-2904

Hoberg EP, Polley L, Jenkins EJ, Kutz SJ (2008) Pathogens of domestic and free-ranging ungulates: global climate change in temperate to boreal latitudes across North America. Rev Sci Tech Off Int Epiz 27(2):511528

Howden SM, Soussana JF, Tubeillo FN, Chhetri N, Dunlop M, Meinke H (2007) Adapting agriculture to climate change. PNAS 104:19691-19696 
Izaurralde RC, Thomson AM, Morgan JA, Fay PA, Polley HW, Hatfield JL (2011) Climate impacts on agriculture: implications for forage and rangeland production. Agron J 103:371-380

Joyce LA, Briske DD, Brown JR, Polley HW, McCarl BA, Bailey DW (2013) Climate change and North American rangelands: assessment of mitigation and adaptation strategies. Rangel Ecol Manag 66(5):512528. doi:10.2111/REM-D-12-00142.1

Kachergis E, Derner JD, Cutts BB, Roche LM, Eviner VT, Lubell MN, Tate KW (2014) Increasing flexibility in rangeland management during drought. Ecosphere 5:1-14

Kates RW, Travis WR, Wilbanks TJ (2012) Transformational adaptation when incremental adaptations to climate change are insufficient. PNAS 109:7156-7161

Khaleel R, Reddy KR, Overcash MR (1981) Changes in soil physical properties due to organic waste applications: a review. J Environ Qual 10:133-141

Krafsur ES, Moon RD (1997) Bionomics of the face fly, Musca autumnalis. Annual Review of Entomol 42:503523

Lark TJ, Salmon JM, Gibbs HK (2015) Cropland expansion outpaces agricultural and biofuel policies in the United States. Environ Res Lett. doi:10.1088/1748-9326/10/4/04.4003

Lysyk TJ (1999) Effect of temperature on time to eclosion and spring emergence of postdiapausing horn flies (Diptera:Muscidae). Environ Entomol 28:387-397

Mader TL (2003) Environmental stress in confined beef cattle. J Ani Sci 81:E110-E119

Mader TL, Dahlquist JM, Gaughan JB (1997) Wind protection effects and airflow patterns in outside feedlots. J Ani Sci 75:26-36

Mader TL, Davis MS, Brown-Brandl T (2006) Environmental factors influencing heat stress in feedlot cattle. J Ani Sci 84:712-719

Marshall NS (2010) Understanding social resilience to climate variability in primary enterprises and industries. Glob Environ Chang 20:36-43

Marshall NA, Smajgl A (2013) Understanding variability in adaptive capacity on rangelands. Rangel Ecol Manag 66:88-94

McCartney D, Basarab JA, Okine EK, Baron VS, Depalme AJ (2004) Alternative fall and winter feeding systems for spring calving beef cows. Can J Ani Sci 84:51-522

Milchunas DG, Mosier AR, Morgan JA, LeCain DR, King JY, Nelson JA (2005) Elevated CO2 and defoliation effects on a shortgrass steppe: forage quality versus quantity for ruminants. Agric Ecosys Environ 111:166184

Mortenson MC, Schuman GE, Ingram LJ, Vayigihugu V, Hess BW (2005) Forage production and quality of a mixed-grass rangeland interseeded with Medicago sativa ssp. falcata. Rangel Ecol Manag 58:505-513

Moss R, Scarlett PL, Kenney MA, Kunreuther HC, Lempert R, Manning J et al (2014) Decision support: connecting science, risk perception, and decisions. In: Melilo JM, Richmond TC, Yohe GW (eds) Climate change impacts in the United States: the third National Climate Assessment. U.S. Global Change Research Program, Washington DC. doi:10.7930/J0H12ZXG

Mueller KE, Blumenthal DM, Pendall E, Carrillo Y, Dijkstra FA, Williams DG, Follett RF, Morgan JA (2016) Impacts of warming and elevated $\mathrm{CO}_{2}$ on a semi-arid grassland are non-additive, shift with precipitation, and reverse over time. Ecol Lett 19:956-966

Muller B, Quaas MF, Frank K, Baumgartner S (2011) Pitfalls and potential of institutional change: rain-index insurance and the sustainability of rangeland management. Ecol Econ 70:2137-2144

Nardone A, Ronchi B, Lacetera N, Ranieri MS, Bernabucci U (2010) Effects of climate change on animal production and sustainability of livestock systems. Livest Sci 130:57-69

National Agricultural Statistics Service (2012) Census of agriculture

Nelson DR, Adger WN, Brown K (2007) Adaptation to environmental change: contributions of a resilience framework. Annu Rev Environ Resour 32:395-419

Nelson R, Kokic P, Crimp S, Howden SM (2010) The vulnerability of Australian rural communities to climate variability and change: part 1-conceptualising and measuring vulnerability. Environ Sci Pol 13:8-17

Peinetti HR, Fredrickson EL, Peters DPC, Cibils AF, Roacho-Estrada JO, Laliberte AS (2011) Foraging behavior of heritage versus recently introduced herbivores on desert landscapes of the American Southwest. Ecosphere 2(5):1-14

Pierce DW, Cayan DR, Thrasher BL (2014) Statistical downscaling using localized constructed analogs (LOCA). J Hydrometeorol 15:2558-2585

Pierce DW, Cayan DR, Maurer EP, Abatzoglou JT, Hegewisch KC (2015) Improved bias correction techniques for hydrological simulations of climate change. J Hydrometeorol 16:2421-2442

Polley HW, Briske DD, Morgan JA, Wolter K, Bailey DW, Brown JR (2013) Climate change and North American rangelands: trends, projections, and implications. Rangel Ecol Manag 66(5):493-511. doi:10.2111/REM-D-12-00068.1 
Rashford BS, Adams RM, Wu J, Voldseth RA, Guntenspergen GR, Werner B, Johnson WC (2016) Impacts of climate change on land use and wetland productivity in the Prairie Pothole Region of North America. Regional Environ Change 16:515-526

Reeves M, Moreno A, Bagne K, Running SW (2014) Estimating the effects of climate change on net primary production of US rangelands. Clim Chang 126:429-442

Reyes-Fox M, Steltzer H, Trlica MJ, McMaster GS, Andales AA, LeCain DR, Morgan JA (2014) Elevated $\mathrm{CO}_{2}$ further lengthens growing season under warming conditions. Nat 510:259-262

Rickards L, Howden SM (2012) Transformational adaptation: agriculture and climate change. Crop \& Pasture Sci 63:240-250

Rinella MJ, Bellows SE (2015) Evidence-targeted grazing benefits to invaded rangelands can increase over extended time frames. Rangel Ecol Manag 69:169-172

Ritten JP, Frasier WM, Bastian CT, Gray ST (2010) Optimal rangeland stocking decisions under stochastic and climate-impacted weather. Am J Agric Econ 92(4):1242-1255. doi:10.1093/ajae/aaq052

Roche LM, Cutts BB, Derner JD, Lubell MN, Tate KW (2015) On-ranch grazing strategies: context for the rotational grazing dilemma. Rangel Ecol Manag 68:248-256

Rose H, Wang T, van Dijk J, Morgan ER (2015) GLOWORM-FL: a simulation model of the effects of climate and climate change on the free-living stages of gastro-intestinal nematode parasites of ruminants. Ecol Model 297:232-245

Ryberg KR, Akyuz FA, Wiche GJ, Lin W (2016) Changes in seasonality and timing of peak streamflow in snow and semi-arid climates of the north-central United States, 1910-2012. Hydrol Process 30:1208-1218

Scasta JD (2015) Livestock parasite management on high-elevation rangelands: ecological interactions of climate, habitat, and wildlife. J Integr Pest Manag 6(1):1-12

Scasta JD, Talley JL, Engle DM, Debinski DM (2017) Climate extremes, vegetation change, and decoupling of interactive fire-grazing processes exacerbate fly parasitism of cattle. Environ Entomol 46:191-200

Shafroth PB, Stromberg JC, Patten DT (2002) Riparian vegetation response to altered disturbance and stress regimes. Ecol Appl 12:107-123

Stockton MC, Adams DC, Wilson RK, Klpenstein TJ, Clark RT, Carriker GI (2007) Production and economic comparisons of two calving dates for beef cows in the Nebraska Sandhills. Prof Anim Sci 23:500-508

St-Pierre NR, Cobanov B, Schnitkey G (2003) Economic losses from heat stress by US livestock industries. J Dairy Sci 86:E52-E77

Tolleson DR, Schafer DW (2014) Application of fecal near-infrared spectroscopy and nutritional balance software to monitor diet quality and body condition in beef cows grazing Arizona rangeland. J Ani Sci 92:349-358

Torell LA, Murugan S, Ramirez OA (2010) Economics of flexible versus conservative stocking strategies to manage climate variability risk. Rangel Ecol Manag 63:415-425

Troy TJ, Kipgen JC, Pal I (2015) The impact of climate extremes and irrigation on US crop yields. Environ Res Letters 10. doi:10.1088/1748-9326/10/5/054013

Vincent K (2007) Uncertainty in adaptive capacity and the importance of scale. Glob Environ Chang 17:12-24

Wright CK, Wimberly MC (2013) Recent land use change in the Western Corn Belt threatens grasslands and wetlands. PNAS 110:4134-4139 